\title{
International Regime Approach in the Development of Indonesia's 2004 Post- Aceh Earthquake and Tsunami Disaster Regulations
}

\author{
Pendekatan Rezim Internasional dalam \\ Perkembangan Peraturan Kebencanaan \\ Indonesia Pasca-Gempa dan Tsunami Aceh \\ 2004
}

\author{
Nathania Dwi Marietta \& Arfin Sudirman \\ Universitas Padjadjaran
}

\begin{abstract}
ABSTRAK
Pada Desember 2004, sebuah tsunami menerjang Aceh, Nias, dan sebagian Sumatera Utara pasca terjadinya gempa berkekuatan 9.O SR, memberikan dampak yang melampaui kapasitas pemerintah Indonesia untuk menanggulanginya sehingga Indonesia harus membuka dirinya terhadap bantuan kemanusiaan internasional. Tetapi, ketiadaan peraturan perundangan yang mengatur segala hal mengenai kebencanaan dan penerimaan bantuan internasional di Indonesia semakin memperkeruh keadaan. Dengan adanya Resolusi Majelis Umum PBB No. 46/182 Tahun 1991 sebagai salah satu wujud rezim internasional, pada tahun 2004 Indonesia dapat menerima bantuan kemanusiaan internasional dengan baik. Tulisan ini bertujuan untuk menelaah perkembangan peraturan perundangan kebencanaan di Indonesia yang terjadi pasca gempa dan tsunami yang menyerang Aceh pada tahun 2004, menggunakan metode kualitatif dengan teknik pengumpulan data berbasis dokumen dan internet serta mewawancarai beberapa ahli. Penemuan menunjukkan adanya perkembangan peraturan perundangan kebencanaan Indonesia yang sejalan dengan hal-hal yang termuat dalam Resolusi Majelis Umum PBB No. 46/182 Tahun 1991, sebagai salah satu wujud partisipasi aktif Indonesia sebagai aktor di dunia internasional. Walau demikian, masih ada beberapa hal yang harus terus dikembangkan Indonesia untuk mencapai hasil yang optimal dalam menanggulangi bencana alam di wilayahnya.
\end{abstract}

Kata-Kata Kunci: Bantuan Kemanusiaan Internasional, Gempa dan Tsunami Aceh 2004, Peraturan Perundangan Kebencanaan Indonesia, Rezim Internasional

In December 2004, a tsunami struck Aceh, Nias, and part of North Sumatra following the 9.O SR magnitude earthquake, of which its impact overwhelmed the Indonesian government's capability and required Indonesia to open itself for international humanitarian assistance. However, the absence of Indonesian disaster regulations and the lack of acceptance for international assistance had worsened the situation. With the UNGA Resolution No. 46/182 of 1991 as a manifestation of the international regime, Indonesia could finally accept international humanitarian assistance in 2004. This article aims to examine the development of Indonesian disaster regulations after the 2004 Aceh earthquake and tsunami, using qualitative methods complimented with document-based and internet-based data as well as interview results with several experts. Findings shows that the development of Indonesian disaster regulations is in line with the matters contained in the resolution, further exhibiting Indonesia's active participation as an actor in the international world. Having said that, there are many things that Indonesia shall continue to develop still in order to achieve optimal results in tackling natural disasters.

Keywords: 2004 Aceh Earthquake and Tsunami, Indonesia Disaster Regulations, International Humanitarian Assistance, International Regimes 
Ancaman keamanan internasional telah berubah seiring dengan berjalannya waktu. Dulu, negara-negara di dunia harus menghadapi ancaman keamanan berupa perang dan ekspansi wilayah. Dewasa ini ancaman keamanan tersebut telah berubah menjadi ancaman non-tradisional yang semakin kompleks dan melibatkan banyak aktor internasional lainnya selain negara. Bencana alam merupakan salah satu dari ancaman non-tradisional tersebut. Sifatnya yang tidak dapat diprediksi secara akurat dan dampak menghancurkan yang ditimbulkannya membuat bencana alam dalam berbagai bentuk menjadi satu isu yang harus diatasi bersama-sama. Hal ini disebabkan tidak semua negara memiliki kemampuan untuk menanggulangi dampak dari bencana alam secara mandiri. Untuk itu, Perserikatan Bangsa-Bangsa (PBB) menyusun sebuah resolusi dasar, Resolusi Majelis Umum PBB No. 46/182 Tahun 1991, yang berguna untuk mengatur pemberian dan penerimaan bantuan kemanusiaan internasional. Resolusi ini kemudian menjadi mandat dasar dari resolusi-resolusi berikutnya, pendirian badan $\mathrm{PBB}$, organisasi internasional dan beberapa hal lainnya yang menyangkut perihal pemberian dan penerimaan bantuan kemanusiaan internasional.

Indonesia pada tahun 2004 pernah menjadi saksi sejarah mengenai betapa dahsyatnya sapuan sebuah tsunami dan bagaimana sulitnya untuk menanggulangi dampak dari bencana tersebut. Beruntung karena kejadian tersebut terjadi jauh setelah Resolusi Majelis Umum PBB No. 46/182 Tahun 1991 dibentuk membuat Indonesia dapat menerima bantuan kemanusiaan internasional dalam jumlah yang besar dan dalam waktu yang singkat. Meskipun demikian, pemerintah Indonesia dianggap tidak siap dalam menerima bantuan kemanusiaan tersebut sebab masih belum adanya peraturan kebencanaan di Indonesia yang komprehensif. Belajar dari kesalahannya, kini Indonesia tumbuh menjadi negara yang mampu untuk mengatasi dampak dari berbagai bencana alam yang kerap kali terjadi di wilayahnya dengan baik. 


\section{Bencana Nasional Pertama yang Menerima Bantuan Kemanusiaan Internasional}

Pada tanggal 26 Desember 2004, dunia berduka. Sebuah gempa tektonik berkekuatan sekitar 9,o skala Richter terjadi di dasar laut barat daya Pulau Simelue (IFRC, 2019). Karena titik pusat gempa yang hanya berjarak sekitar 200 kilometer dari Banda Aceh, dengan kecepatan $600-800 \mathrm{~km} / \mathrm{jam}$, dalam waktu singkat gelombang tsunami tersebut berhasil memorak-porandakan hampir seluruh wilayah pesisir Nanggroe Aceh Darussalam, Nias, dan sebagian wilayah Sumatera Utara. Dalam hitungan jam, gelombang tsunami yang disebabkan oleh gempa terbesar keempat di dunia sejak 1900 ini, juga berhasil meluluhlantakkan beberapa negara lainnya yang berada di sekitar Indonesia seperti Thailand, Malaysia, Bangladesh, India, Sri Lanka, Maladewa, dan beberapa negara di Afrika seperti Somalia, Kenya, dan Tanzania. Ratusan ribu orang menjadi korban jiwa, berbagai infrastruktur yang ada rata dengan tanah, dan pemerintah daerah pun lumpuh total. Dahsyatnya dampak sapuan gelombang tsunami tersebut membuat pemerintah harus segera mengambil tindakan. Maka dari itu, setelah menimbang situasi yang ada dan merundingkan laporan yang masuk secara langsung, akhirnya Presiden Susilo Bambang Yudhoyono menyatakan bahwa bencana alam gempa dan tsunami saat itu merupakan bencana nasional dan hari berkabung nasional. Pernyataan nasional ini dituangkan dalam Keputusan Presiden No. 112 Tahun 2004. Dengan dikeluarkannya keputusan presiden ini, secara tidak langsung Indonesia membuka pintunya lebar-lebar untuk bantuan kemanusiaan internasional.

Namun pada saat bencana nasional ini terjadi, kesiapan Indonesia dalam menghadapi bencana alam masih sangat kurang. Hal ini terbukti dari belum adanya Undang-Undang penanggulangan bencana yang komprehensif untuk mengarahkan upaya bantuan nasional maupun internasional (Bannon 2005). Pada saat itu, lembaga kebencanaan telah ada, namun lembaga tersebut tidak dapat menanggulangi bencana sebesar itu dengan baik dan mandiri. Badan Koordinasi Nasional Penanggulangan Bencana dan Penanganan Pengungsi (Bakornas PBP), yang merupakan lembaga kebencanaan pada tahun 2004, dan pemerintah pusat akhirnya memutuskan untuk membentuk Badan Rekonstruksi 
dan Rehabilitasi (BRR) Aceh Nias dengan tugas utama yaitu memulihkan keadaan daerah terdampak gempa dan tsunami tersebut. Selain ketiadaan peraturan perundangan yang baik guna mengaturberbagaihalterkaitkebencanaan dalamnegeri,Indonesia juga tidak memiliki peraturan perundangan yang mengatur perihal penerimaan bantuan kemanusiaan internasional, salah satu bentuk dari bantuan internasional tersebut adalah pasukan militer asing. Saat itu, diketahui bahwa Indonesia merupakan negara yang menerima bantuan kemanusiaan internasional terbesar dibandingkan dengan negara-negara lainnya yang juga terkena dampak dari gempa dan tsunami tersebut. Indonesia menerima bantuan dalam berbagai bentuk seperti kucuran dana, barangbarang logistik, proyek-proyek yang dilakukan oleh IGO dan NGO internasional serta 3.961 pasukan militer asing dari 11 negara berbeda (Wiharta 2008). Jadi, pada tahun 2004 silam Indonesia menerima bantuan kemanusiaan internasional tanpa adanya peraturan perundangan yang khusus mengatur berbagai bentuk bantuan kemanusiaan internasional yang masuk ke wilayahnya, khususnya pasukan militer asing yang dapat melakukan aktivitas di luar tujuan kemanusiaan karena sifat militer yang dekat dengan politik pemerintah asalnya.

Namun demikian berkat Resolusi Majelis Umum PBB No. 46/182 Tahun 1991 yang mengatur perihal penguatan koordinasi bantuan darurat kemanusiaan internasional, Indonesia dapat menerima bantuan kemanusiaan internasional tanpa timbulnya permasalahan baru yang berhubungan dengan kedaulatan wilayahnya. Meskipun Indonesia secara resmi tidak pernah menyatakan salah satu bentuk rezim internasional ini sebagai landasan saat menerima bantuan internasional di tahun 2004, Indonesia telah meratifikasi resolusi ini sehingga Indonesia harus mengakui dan menghormati resolusi ini. Rezim internasional merupakan sebuah konsep penting dalam Hubungan Internasional selama lebih dari dua dekade ke belakang, sehingga banyak ahli yang kemudian menuangkan pemikirannya mengenai konsep ini. Namun, pemikiran ahli yang paling dikenal mengenai definisi rezim internasional adalah definisi yang dikemukakan oleh Stephen D. Krasner yang menyebutkan bahwa rezim internasional adalah serangkaian prinsip, norma, aturan dan prosedur pembuat keputusan, baik yang bersifat implisit maupun eksplisit, di mana 
ekspektasi aktor-aktor internasional bertemu dalam suatu bidang tertentu dalam hubungan internasional (Krasner 1983, 3). Rezim internasional dapat berupa beragam bentuk seperti perjanjian internasional, kerja sama internasional, organisasi internasional, resolusi $\mathrm{PBB}$, kesepakatan internasional, dan lain sebagainya. Dengan demikian, Resolusi Majelis Umum PBB No. 46/182 Tahun 1991 ini dapat dianggap sebagai salah satu wujud rezim internasional.

\section{Kesiapan Indonesia dalam Menerima Bantuan Internasional Pada Saat Gempa dan Tsunami Aceh 2004}

Gempa dan Tsunami Aceh 2004 dapat diumpamakan sebagai sebuah tamparan keras bagi Indonesia sebab peristiwa ini menunjukkan bahwa banyak hal yang harus diperbaiki dalam bidang kesiapan menghadapi kebencanaan. Untuk itu, banyak hal yang kemudian disempurnakan oleh pemerintah pasca tahun 2004 khususnya dalam bidang peraturan perundangan mengenai kebencanaan yang sering terjadi di wilayah negara kesatuan ini. Sebab, peraturan perundangan tertulis nasional adalah awal mula dari perkembangan aspek penting lainnya seperti contohnya adalah BNPB yang didirikan setelah munculnya UU No. 24 tahun 2007 tentang Penanggulangan Bencana dan diatur melalui Peraturan Presiden No. 8 tahun 2008 tentang Badan Nasional Penanggulangan Bencana. Berikut adalah beberapa hal yang menunjukkan kurang siapnya Indonesia dalam mengatasi dampak Gempa dan Tsunami Aceh 2004. Pertama, pada saat menerima bantuan kemanusiaan internasional di tahun 2004 Indonesia belum memiliki peraturan perundangan yang mengatur berbagai hal berkaitan dengan isu tersebut. Saat kabar mengenai bencana yang menimpa beberapa negara sekaligus ini didengar oleh dunia internasional, berbagai pihak seperti PBB, negara-negara, IGO, dan NGO langsung mencari informasi mengenai keadaan wilayah Indonesia yang terdampak bencana tersebut melalui Kementerian Luar Negeri Indonesia (Zaidan 2019). Setelah mendapatkan informasi bahwa keadaan di Aceh dan beberapa titik lainnya pada saat itu sangat mengerikan, pihak-pihak internasional tersebut kemudian berbondong-bondong menawarkan berbagai bentuk bantuan untuk meringankan beban para korban. Indonesia yang 
pada saat itu belum berpengalaman dalam menghadapi bencana nasional dengan baik, memutuskan untuk menerima segala bentuk bantuan kemanusiaan internasional termasuk pasukan militer asing di dalamnya tanpa adanya peraturan perundangan yang kuat guna mengatur berbagai hal terkait kebencanaan dan penerimaan bantuan kemanusiaan internasional.

Bantuan yang datang pada saat itu sangat membantu masyarakat Aceh dalam fase tanggap darurat (Maulana 2020). Pada saat itu, pemerintah daerah lumpuh total sehingga Aceh mengandalkan bantuan yang diberikan oleh pemerintah pusat dan internasional. Selain bantuan berupa barang-barang logistik yang termasuk ke dalam kebutuhan primer untuk bertahan hidup, para korban juga sangat mengapresiasi pertolongan yang ditawarkan oleh pasukan militer asing berupa aset militer dan teknologi yang turut mereka bawa dari negara asalnya. Tidak dapat dipungkiri bahwa terdapat banyak teknologi canggih yang belum dimiliki oleh Indonesia, diperkenalkan oleh pasukan militer asing serta pegiat organisasi internasional yang saat itu datang ke Aceh. Potensi permasalahan muncul saat masuknya orang asing ke Indonesia, baik itu personel militer maupun pegiat organisasi internasional, tanpa melalui prosedur di bagian imigrasi seperti biasanya. Dalam situasi darurat, penjagaan imigrasi tidak bisa seketat biasanya (Zaidan 2019). Hal ini terjadi karena keterbatasan waktu yang dimiliki oleh pihak imigrasi untuk memeriksa setiap orang asing yang masuk secara menyeluruh. Ditambah lagi dengan adanya kebijakan yang dibuat pemerintah Indonesia untuk mempermudah proses masuknya orang asing ke Indonesia demi penyampaian bantuan yang lebih cepat. Meskipun militer asing dan pegiat organisasi internasional yang masuk saat itu juga memiliki tenggat waktunya sendiri, tidak menutup kemungkinan adanya penyalahgunaan wewenang yang dapat mereka lakukan tanpa sepengetahuan Indonesia. Terlebih lagi mengingat kondisi yang saat itu masih menegang antara pemerintah Indonesia dengan para kombatan kelompok separatisme, GAM. Sehingga, merupakan suatu tindakan yang berisiko tinggi saat Indonesia membuka pintunya bagi orang asing khususnya militer asing untuk dapat beroperasi di wilayahnya tanpa ada peraturan yang jelas yang mengatur mengenai fenomena tersebut, meskipun dengan tujuan awal yang berupa tujuan kemanusiaan. 
Berikutnya, Indonesia merupakan negara terdampak yang menerima jumlah bantuan internasional terbesar dibandingkan dengan negara-negara lainnya. Sehingga dapat dibayangkan seberapa banyak jumlah bantuan yang diterima oleh Indonesia, namun sayangnya banyak dari bantuan tersebut yang tidak tepat sasaran dan akhirnya hanya menjadi sampah. Obat-obatan kedaluwarsa, makanan kedaluwarsa, pakaian bekas yang tidak layak pakai, proyek-proyek organisasi internasional yang tidak tepat waktu juga tempat dan lain sebagainya. Hal ini terjadi karena tidak adanya panduan bagi pihak donatur dalam memberikan bantuan berupa daftar barang atau hal-hal apa saja yang tidak dapat disediakan oleh pemerintah Indonesia kepada rakyatnya sehingga membutuhkan bantuan dari luar negeri. Keadaan diperburuk dengan situasi yang tidak mendukung bagi pihak bea cukai dan BPOM untuk memeriksa setiap bantuan berupa barang yang masuk ke Indonesia secara menyeluruh karena keterbatasan waktu (Zaidan 2019). Hal ini sungguh disayangkan, mengingat bantuan yang dikirimkan oleh pihak internasional tersebut, terlebih lagi bantuan yang dikirimkan oleh aktor negara, akan tercatat dalam sejarah Indonesia. Negara donatur akan terus memperbincangkan bantuan yang telah mereka berikan kepada Indonesia di kancah internasional dan berharap nantinya jika mereka membutuhkan bantuan, Indonesia juga akan memberikan bantuan kepada mereka (Zaidan 2019). Jadi, akan lebih baik jika bantuan yang diberikan oleh negara-negara tersebut memang benar-benar berguna bagi korban yang terkena bencana alam.

Selanjutnya adalah kurangnya persiapan lembaga kebencanaan Indonesia pada tahun 2004. Sesungguhnya saat itu Indonesia telah memiliki suatu lembaga khusus yang tugasnya diperuntukkan untuk menanggulangi berbagai bencana, yaitu Bakornas PBP. Tetapi karena keterbatasan pengalaman dalam menanggulangi bencana nasional dan tidak adanya peraturan yang mengatur berbagai hal teknis yang sangat penting pada saat eksekusi penanggulangan bencana di lapangan secara terperinci, lembaga ini tidak dapat menanggulangi bencana Gempa dan Tsunami Aceh secara mandiri. Maka dari itu, dibentuklah BRR Aceh Nias yang merupakan salah satu upaya Bakornas PBP dan pemerintah Indonesia untuk memulihkan keadaan wilayah terdampak dengan berbagai macam program rekonstruksi dan rehabilitasi di Aceh 
dan Nias dalam kurun waktu empat tahun. Namun demikian, respons tanggap TNI sebagai salah satu instansi negara yang berkewajiban untuk memastikan keamanan dan keselamatan masyarakat Indonesia patut diapresiasi. Undang-Undang yang mengatur mengenai tugas Operasi Militer Selain Perang (OMSP) TNI yang di dalamnya termasuk penanggulangan bencana alam baru diresmikan pada tanggal 16 Oktober 2004, meskipun dengan selang waktu hanya beberapa bulan mereka dapat melakukan tugasnya dengan baik dalam penanggulangan bencana. Kesigapan dan jumlah para personel TNI yang mumpuni memberikan dampak besar bagi para korban, sebab tidak hanya membantu dalam aspek logistik dan tenaga bantuan, para personel TNI yang tergabung dalam Komando Tugas Gabungan Terpadu (Kogasgabpad) juga memberikan pertolongan dalam bentuk medis, trauma healing, psikologi dan bina mental yang sangat dibutuhkan oleh korban pada saat itu (Wijayanto 2019).

Eksekusi penanggulangan bencana yang dilakukan pemerintah sesungguhnya sudah cukup memuaskan, khususnya terkait pendistribusian bantuan dari dalam dan luar negeri (Maulana 2020). Tetapi akan jauh lebih baik jika ada peraturan perundangan yang mengatur seluruh hal terkait kebencanaan secara terperinci guna semakin memperkuat keamanan dan pertahanan negara Indonesia. Sebab isu wilayah di sini menjadi sorotan utama jika ada pasukan militer asing yang masuk tanpa adanya peraturan yang mengatur secara ketat meskipun kedatangan mereka dengan tujuan kemanusiaan. Dengan demikian, dapat disimpulkan bahwa keadaan pada saat 2004 silam bersifat tidak sejalan, artinya keadaan di lapangan berbeda dengan keadaan peraturan perundangan di Indonesia. Kesiapan instansi dan lembaga dalam negeri yang terjun langsung ke lapangan dapat dikategorikan jauh lebih baik jika dibandingkan dengan kesiapan pemerintah khususnya dalam segi peraturan perundangan dalam mengantisipasi bencana dan penerimaan bantuan kemanusiaan internasional. Karena peraturan perundangan kebencanaan yang ada saat itu tidak terperinci serta berfokus pada respons saat terjadinya bencana saja. 


\section{Analisis Resolusi 46/182 dalam Kebijakan Kebencanaan Indonesia}

Saat Gempa dan Tsunami Aceh 2004 terjadi, pemerintah Indonesia tidak memberikan perhatian lebih terhadap perjanjian internasional dalam bentuk resolusi yang membahas perihal bantuan kemanusiaan internasional (Zaidan 2019). Indonesia secara resmi tidak menyebut satu resolusi pun perihal penanggulangan bencana di Aceh ini. Keadaan ini sangat disayangkan sebab sesungguhnya Indonesia dapat menjadikan resolusi PBB sebagai landasan bagi kebijakan Indonesia untuk menerima bantuan kemanusiaan internasional, khususnya militer asing di saat absennya peraturan perundangan yang ajek di dalam negeri. Memang pada praktiknya, setiap negara atau organisasi yang hendak masuk ke Indonesia untuk memberikan bantuan berupa tenaga ahli atau pasukan militer asing akan melewati proses perbincangan bilateral terlebih dahulu. Hal ini sesuai dengan Piagam PBB yang mengutamakan kedaulatan suatu negara. Meskipun demikian, kerangka kerja umum dan dasar perihal penerimaan bantuan kemanusiaan internasional mutlak juga dibutuhkan oleh Indonesia. Selain untuk memastikan kedaulatan dan keamanan negara, peraturan perundangan ini juga diperlukan untuk mempermudah dan mempercepat proses perbincangan bilateral yang merupakan sebuah proses yang tidak bisa ditiadakan.

Meskipun Indonesia tidak pernah mendeklarasikan sebuah resolusi PBB sebagai landasan kebijakan Indonesia dalam menerima bantuan kemanusiaan internasional khususnya militer asing pada tahun 2004 secara formal, Indonesia sebagai salah satu anggota PBB dan dunia internasional tetap menghormati perjanjian internasional yang ada dan berlaku di dunia internasional yang mengatur perihal pemberian dan penerimaan bantuan kemanusiaan internasional (Zaidan 2019). Maka dari itu, untuk menganalisis fenomena penerimaan bantuan kemanusiaan internasional di Indonesia pada tahun 2004, tulisan ini akan menggunakan salah satu teori yang ada di Hubungan Internasional yaitu Rezim Internasional. Rezim Internasional dapat berupa berbagai bentuk, namun rezim internasional yang penulis bahas di sini adalah sebuah resolusi yang dikeluarkan oleh 
International Regime Approach in the Development of Indonesia's 2004 Post-Aceh Earthquake and Tsunami Disaster Regulations

Majelis Umum PBB dengan nomor dokumen 46/182 tahun 1991 mengenai Strengthening of the coordination of humanitarian emergency assistance of the United Nations.

Dalam teori rezim internasional terdapat tiga pendekatan yang menjelaskan signifikansi rezim internasional di sistem internasional. Untuk menjelaskan fenomena penerimaan bantuan kemanusiaan internasional yang dilakukan oleh Indonesia pada tahun 2004, tulisan ini menganggap pendekatan modified structuralism merupakan pendekatan yang tepat. Pendekatan yang dikemukakan oleh Arthur A. Stein dan Robert Keohane ini menjelaskan bahwa signifikansi suatu rezim internasional hanya akan menjadi berarti saat aktor negara mengalami keadaan suboptimal sehingga mereka membutuhkan rezim internasional untuk memaksimalkan hasil yang akan mereka capai.

Pada tanggal 19 Desember 1991, Majelis Umum PBB meresmikan resolusi 46/182 sebagai fondasi awal dan kerangka kerja bagi perjanjian internasional atau rezim internasional lainnya yang membahas mengenai bantuan kemanusiaan internasional di kemudian hari. Hal ini dilakukan untuk meningkatkan komunikasi dan rasa kepercayaan antarnegara di dunia internasional agar sama-sama berkontribusi dalam penguatan koordinasi penyampaian bantuan keamanan dalam situasi darurat di lingkup internasional. Sehingga setiap negara yang tergabung dalam PBB diharapkan untuk menghormati dan mematuhi setiap peraturan yang termuat dalam resolusi ini. Dalam resolusi ini dimuat berbagai hal yang mengatur pemberian dan penerimaan bantuan kemanusiaan dalam keadaan darurat, termasuk di dalamnya adalah keadaan darurat yang disebabkan oleh bencana alam. Hal pertama yang ditegaskan dalam resolusi ini adalah:

"Bantuan kemanusiaan harus diberikan sesuai dengan prinsip-prinsip kemanusiaan, netralitas, dan imparsial. Kemudian kedaulatan, integritas teritorial, dan kesatuan nasional negara harus sepenuhnya dihormati sesuai dengan Piagam PBB”. (Resolusi Majelis Umum PBB No. 46/182 tahun 1991)

Artinya, semua pemberian bantuan kemanusiaan internasional kepada negara yang membutuhkan harus didasari oleh 
penghormatan atas kedaulatan negara yang bersangkutan serta hanya bertujuan pada aktivitas kemanusiaan saja. Resolusi ini secara tegas menyatakan bahwa pemberian bantuan kemanusiaan internasional harus sesuai dengan persetujuan negara penerima sehingga tidak ada bantuan kemanusiaan yang diberikan dengan paksaan. Selain itu, negara penerima memegang peranan utama dalam aktivitas kemanusiaan ini. Negara penerima merupakan pihak yang akan menginisiasi, mengorganisasi, dan mengoordinasi pelaksanaan bantuan kemanusiaan di wilayahnya. Maka sangat disarankan untuk negara penerima bantuan untuk mengkomunikasikan kembali perihal kerja sama ini secara bilateral dengan negara, IGO atau NGO yang hendak memberikan bantuan melalui perbincangan bilateral. Belajar dari kesalahan masa lalunya, kini Indonesia mulai menyusun kebijakan yang sejalan dengan resolusi ini, hal ini dapat terlihat dari perkembangan kondisi kebencanaan Indonesia dewasa ini. Berikut adalah analisis mengenai implementasi Resolusi 46/182 Tahun 1991 dalam kebijakan kebencanaan Indonesia sebelum dan setelah Gempa dan Tsunami Aceh 2004 yang termuat dalam tabel di bawah ini.

Tabel 1.

Implementasi Resolusi 46/182 Tahun 1991 sebelum dan setelah Gempa dan Tsunami Aceh 2004

\begin{tabular}{|c|c|c|}
\hline $\begin{array}{l}\text { Indonesia sebelum dan } \\
\text { saat Gempa dan Tsunami } \\
\text { Aceh } 2004\end{array}$ & $\begin{array}{c}\text { Resolusi } \\
\text { Majelis Umum } \\
\text { PBB No. } \\
\text { 46/182 Tahun } \\
\text { 1991 }\end{array}$ & $\begin{array}{c}\text { Indonesia setelah Gempa dan } \\
\text { Tsunami Aceh } 2004\end{array}$ \\
\hline $\begin{array}{l}\text { Tidak ada peraturan } \\
\text { perundangan nasional yang } \\
\text { mengatur perihal kerja } \\
\text { sama Indonesia dengan } \\
\text { dunia internasional dalam } \\
\text { mengatasi situasi darurat } \\
\text { melalui pemberian dan } \\
\text { penerimaan bantuan } \\
\text { kemanusiaan internasional. }\end{array}$ & $\begin{array}{c}\text { "Kerja sama } \\
\text { internasional } \\
\text { untuk mengatasi } \\
\text { situasi darurat } \\
\text { harus dijalankan } \\
\text { sesuai dengan } \\
\text { hukum } \\
\text { internasional } \\
\text { dan hukum } \\
\text { nasional" }\end{array}$ & $\begin{array}{l}\text { Ada peraturan perundangan } \\
\text { nasional yang mengatur perihal } \\
\text { kerja sama Indonesia dengan pihak } \\
\text { internasional dalam mengatasi } \\
\text { situasi darurat khususnya bencana } \\
\text { alam yang dituangkan dalam } \\
\text { Peraturan Pemerintah No. } 23 \\
\text { tahun } 2008 \text { tentang Peran Serta } \\
\text { Lembaga Internasional dan } \\
\text { Lembaga Asing Nonpemerintah } \\
\text { dalam Penanggulangan Bencana. }\end{array}$ \\
\hline
\end{tabular}




\begin{tabular}{|c|c|c|}
\hline $\begin{array}{l}\text { Pemerintah Indonesia } \\
\text { lebih banyak berfokus } \\
\text { pada penanggulangan saat } \\
\text { terjadinya bencana, yang } \\
\text { terlihat dari isi peraturan } \\
\text { perundangan yang mengatur } \\
\text { lembaga kebencanaan } \\
\text { Indonesia. Salah satu } \\
\text { contohnya adalah Kepres } \\
\text { no. } 3 \text { tahun } 2001 \text { tentang } \\
\text { Badan Koordinasi Nasional } \\
\text { Penanggulangan Bencana dan } \\
\text { Pengungsi. }\end{array}$ & $\begin{array}{l}\text { "Perhatian } \\
\text { khusus harus } \\
\text { diberikan pada } \\
\text { pencegahan dan } \\
\text { kesiapsiagaan } \\
\text { bencana oleh } \\
\text { pemerintah } \\
\text { terkait" }\end{array}$ & $\begin{array}{l}\text { Pemerintah mulai memberikan } \\
\text { perhatian khusus kepada fase } \\
\text { prabencana dalam penanggulangan } \\
\text { bencana nasional, yang tertuang } \\
\text { dalam UU No. } 24 \text { tahun } 2007 \\
\text { tentang Penanggulangan Bencana. } \\
\text { Dalam peraturan ini dimuat } \\
\text { bahwa pendidikan, pelatihan, dan } \\
\text { keterampilan menghadapi bencana } \\
\text { merupakan hak setiap masyarakat } \\
\text { Indonesia yang harus diberikan } \\
\text { oleh pemerintah. }\end{array}$ \\
\hline $\begin{array}{l}\text { Saat Gempa dan Tsunami } \\
\text { Aceh terjadi, komando } \\
\text { di lapangan memang } \\
\text { dipegang oleh pemerintah } \\
\text { Indonesia, tetapi hal ini tidak } \\
\text { dilandasi oleh peraturan } \\
\text { perundangan sehingga } \\
\text { adanya ketidakaturan dan } \\
\text { berpotensi menjadi masalah, } \\
\text { salah satunya adalah } \\
\text { miskomunikasi. }\end{array}$ & $\begin{array}{l}\text { "Karenanya } \\
\text { negara yang } \\
\text { terkena dampak } \\
\text { memiliki } \\
\text { peran utama } \\
\text { dalam inisiasi, } \\
\text { organisasi, } \\
\text { koordinasi, dan } \\
\text { pelaksanaan } \\
\text { bantuan } \\
\text { kemanusiaan } \\
\text { di dalam } \\
\text { wilayahnya" }\end{array}$ & $\begin{array}{l}\text { Kini peran utama dalam memegang } \\
\text { komando saat terjadi bencana alam } \\
\text { akan dipegang oleh BNPB selaku } \\
\text { lembaga kebencanaan Indonesia } \\
\text { saat ini. Hal ini telah diatur } \\
\text { dalam Perka BNPB No. } 3 \text { tahun } \\
2016 \text { tentang Sistem komando } \\
\text { penanganan darurat bencana. }\end{array}$ \\
\hline $\begin{array}{l}\text { Perihal pendanaan untuk } \\
\text { bencana alam sudah ada } \\
\text { namun segala pendanaan } \\
\text { terkait kebencanaan } \\
\text { dibebankan pada APBN, } \\
\text { APBD, dan masyarakat tanpa } \\
\text { ada rincian yang jelas. }\end{array}$ & $\begin{array}{l}\text { "Kebutuhan } \\
\text { akan mekanisme } \\
\text { pendanaan pusat } \\
\text { yang saling } \\
\text { melengkapi } \\
\text { untuk } \\
\text { memastikan } \\
\text { penyediaan } \\
\text { sumber daya } \\
\text { yang memadai } \\
\text { untuk digunakan } \\
\text { pada fase awal } \\
\text { darurat yang } \\
\text { memerlukan } \\
\text { respons seluruh } \\
\text { sistem" }\end{array}$ & $\begin{array}{l}\text { Seperti sebelumnya, pendanaan } \\
\text { untuk kebencanaan berasal dari } \\
\text { APBN, APBD, dan masyarakat. } \\
\text { Dengan rincian (a) dana } \\
\text { kontingensi bencana, (b) dana } \\
\text { siap pakai, (c) dana bantuan sosial } \\
\text { berpola hibah. } \\
\text { Ketentuan lebih lanjut mengenai } \\
\text { mekanisme pengelolaan dana } \\
\text { penanggulangan bencana tertuang } \\
\text { dalam Peraturan Pemerintah No. } \\
22 \text { Tahun 2008 tentang Pendanaan } \\
\text { dan Pengelolaan Bantuan Bencana. }\end{array}$ \\
\hline
\end{tabular}




\begin{tabular}{|l|c|l|}
\hline Belum adanya kesadaran & "Peningkatan & Pemerintah menekankan \\
yang terlihat dari peraturan & kesadaran & pentingnya mitigasi bencana \\
perundangan tertulis & akan perlunya & seperti yang tertuang dalam \\
mengenai wilayah Indonesia & menetapkan & UU No. 24 tahun 2007 tentang \\
yang rawan terhadap bencana & strategi mitigasi & Penanggulangan Bencana Pasal \\
alam. Dalam peraturan yang & bencana, & 47. Dan juga adanya peningkatan \\
ada hanya menyebutkan & terutama di & kesadaran bahwa Indonesia \\
kata "pencegahan" tanpa ada & negara-negara & adalah wilayah yang rawan \\
penjelasan lebih lanjut. & yang rawan & bencana, terlihat dari frasa \\
& bencana" & "menimbang' di beberapa peraturan \\
& & perundangannya yang membahas \\
tentang kebencanaan.
\end{tabular}

Sumber: dikumpulkan oleh penulis

Melalui tabel di atas dapat diperhatikan bahwa sudah adanya kesadaran pemerintah Indonesia terhadap pentingnya peraturan perundangan maupun kebijakan perihal kebencanaan guna memerangi berbagai bentuk bencana. Dengan demikian, dapat dikatakan bahwa pemerintah Indonesia sudah mulai menjadikan ancaman bencana sebagai salah satu hal yang harus dijadikan fokus utama. 
Namun, hal yang disayangkan adalah fakta bahwa dari 2004 hingga saat ini Indonesia belum memiliki peraturan perundangan yang spesifik mengatur perihal penerimaan bantuan kemanusiaan internasional dalam bentuk pasukan militer. Mengingat resolusi ini telah ada sejak tahun 1991 dan ditambah lagi dengan keikutsertaan Indonesia dalam penyusunan Oslo Guidelines pada tahun 1994, yang merupakan kerangka kerja lanjutan dari resolusi ini untuk mengatur kerja sama militer asing dan sipil lokal dalam pemberian dan penerimaan bantuan kemanusiaan internasional. Sedangkan resolusi ini dengan jelas menyatakan bahwa dibutuhkannya peraturan nasional dan inisiasi negara penerima bantuan dalam mengatur berbagai hal yang bersangkutan dengan penerimaan bantuan kemanusiaan internasional ini. Selain itu, dalam sistem internasional pun posisi peraturan nasional akan lebih diutamakan jika disandingkan dengan suatu rezim internasional atau perjanjian internasional. Karena rezim internasional berperan sebagai norm settings dalam sistem internasional yang mengatur hubungan antarnegara, sehingga dalam fenomena pengiriman bantuan kemanusiaan internasional ke sebuah negara, peraturan nasional yang berlaku di negara tersebut akan lebih kuat untuk mengatur segalanya. Jadi, seharusnya Indonesia dapat mempersiapkan dirinya lebih baik lagi pada tahun 2004, mengingat Indonesia telah mengalami banyak bencana alam sebelumnya. Namun demikian, ketiadaan peraturan perundangan yang mengatur bantuan kemanusiaan internasional berupa pasukan militer ini akan dimaklumi jika Indonesia menentang masuknya pasukan militer asing apa pun tujuannya karena alasan kedaulatan serta pertahanan. Untuk itu, Indonesia perlu memperkuat koordinasi dalam negeri dan terus melatih TNI agar mahir menangani berbagai bencana alam yang dapat terjadi di Indonesia sebab setiap bencana alam memiliki cara penanggulangannya masing-masing.

\section{Simpulan}

Peraturan perundangan kebencanaan Indonesia telah banyak berkembang sejak terjadinya Gempa dan Tsunami Aceh di tahun 2004. Selain peraturan perundangan, Indonesia juga semakin memperjelas prosedur dan alur kerja sama antar instansi di 
dalam negeri saat terjadinya bencana alam. Tidak menutup diri dari bantuan kemanusiaan internasional, Indonesia juga menyusun peraturan perundangan yang mengatur penerimaan bantuan kemanusiaan internasional ke dalam wilayahnya. Tetapi, di saat yang bersamaan Indonesia juga semakin membatasi keterlibatan pasukan militer asing dalam penanggulangan bencana di wilayahnya. Kebijakan ini akan bijak jika turut diikuti oleh peningkatan pelatihan TNI dalam menanggulangi bencana sebagai salah satu OMSP mereka sebab tidak dapat dipungkiri bahwa masih banyak hal yang harus dipelajari TNI dari militer negara maju yang telah lebih sering melakukan OMSP di berbagai wilayah.

Mayoritas dari perkembangan peraturan perundangan kebencanaan Indonesia dinilai sejalan dengan hal-hal yang tertuang dalam Resolusi Majelis Umum PBB No. 46/182 sebagai salah satu bentuk rezim internasional. Hal ini dinilai sebagai salah satu wujud kasus modified structuralism, yaitu Indonesia mendapatkan hasil yang sub-optimal saat menghadapi bencana alam tanpa adanya peraturan perundangan yang jelas, kemudian menjadikan resolusi ini sebagai panduan untuk membangun peraturan nasionalnya demi mendapatkan hasil yang optimal. Namun demikian, hingga saat ini kemampuan Indonesia menanggulangi bencana belum sebaik Jepang yang sering kali dijadikan panutan oleh Indonesia dalam bidang kebencanaan. Edukasi kebencanaan yang belum dipupuk pada masyarakat sejak usia belia, teknologi yang belum terlalu canggih, alat pendeteksi bencana yang belum memadai, kurangnya alokasi dana untuk alat-alat pendeteksi bencana di setiap wilayah rawan bencana dan sederet alasan lainnya masih menjadi tantangan bagi Indonesia. Oleh karena itu, diharapkan ke depannya Indonesia akan terus dan semakin menganggap topik kebencanaan sebagai salah satu ancaman keamanan non-tradisional yang penting sehingga dapat memaksimalkan pencegahan dan mitigasi bencana. Karena selain dapat menyelamatkan banyak nyawa dan materiel, mitigasi bencana yang baik juga dapat menjadi kesempatan bagi Indonesia untuk bersinar di kancah internasional sebagai negara yang tangguh menghadapi bencana alam dan layak menjadi panutan bagi negara-negara lain. 
International Regime Approach in the Development of Indonesia's 2004 Post-Aceh Earthquake and Tsunami Disaster Regulations

\section{Referensi}

\section{Buku dan Bab dalam Buku}

Purwanto, Eddy, 2009. Breakthrough Thousands of Paths toward Resolution. New York: UNDP Press.

Haas, E.B. 1983. "Words can hurt you; or, who said what to whom about regimes", dalam Krasner, S.D. (ed.), 1983. International Regimes. London: Cornell University.

Ikawati, Y. 2005. "Lebih Jauh Dengan Dr Danny Hilman Natawijaya", dalam Cahanar, P., 2005. Bencana Gempa dan Tsunami Nanggroe Aceh Darussalam \& Sumatera Utara. Jakarta: Buku Kompas.

Keohane, R.O., 1983. "The Demand of International Regimes" dalam Krasner, S.D. (ed.), 1983. International Regimes. London: Cornell University.

Krasner, S.D. (ed.), 1983. International Regimes. London: Cornell University Press.

Wiharta, Sharon, et al., 2008. The Effectiveness of Foreign Military Assets in Natural Disaster Response. Solna: Stockholm International Peace Research Institute.

Sudirman, A., dan A. Chasya, 2016. Implementasi Rezim Internasional Anti Trafficking in Persons Pada Kasus Indonesia-Malaysia. Bandung: Unpad Press.

Nugroho, Sutopo Purwo, et al., 2015. BNPB Profile. Jakarta: Pusat Data, Informasi dan Hubungan Masyarakat BNPB.

\section{Dokumen Resmi}

Majelis Umum PBB, 1991. Resolusi No. 46/182 Tahun 1991 [daring]. dalam https://documents-dds-ny.un.org/doc/ RESOLUTION/GEN/NRo/582/70/IMG/NR058270. pdf?OpenElement [diakses pada 2 September 2021].

UNOCHA, 1994. Oslo Guidelines. Oslo: UNOCHA. 


\section{Wawancara}

Maulana, M., 2020. "Dosen Fakultas Hukum Universitas Padjadjaran”, diwawancarai oleh N.D. Marietta, 20 Januari 2020.

Wibowo, A., 2019. "Kepala Pusat Data Informasi dan Humas BNPB”, diwawancarai oleh N.D. Marietta, 17 Desember 2019.

Wijayanto, B.J., 2019. "Direktur Umum Akademi TNI", diwawancarai oleh N.D. Marietta, 19 Desember 2019.

Zaidan, A., 2019. "Staff Direktorat Hak Asasi Manusia dan Kemanusiaan Kementerian Luar Negeri”, diwawancarai oleh N.D. Marietta, 17 Desember 2019.

\section{Artikel Daring}

ICRC, 2005. Protocol additional to the Geneva Conventions of 12 August 1949, and relating to the Adoption of an Additional Distinctive Emblem (Protocol III) [daring]. dalam https:// www.icrc.org/en/doc/resources/documents/misc/ treaties-third-protocol-emblem-081205.htm [diakses pada 2 September 2021].

IFRC, 2019. Indian Ocean Tsunami [daring]. dalam https://www. ifrc.org/tsunami [diakses pada 15 Mei 2019].

Harkin, C., 2005. "The 2004 Tsunami: Civil Military Aspects of the International Response". Tsunami Evaluation Coalition [daring]. dalam https://www.alnap.org/system/files/ content/resource/files/main/coordination civil military. pdf [diakses pada 2 September 2021].

\section{Lain-lain}

Bannon, V. 2005. Indonesia: Laws, Policies, Planning and Practices on International Disaster Response. Bangkok: International Federation of Red Cross and Red Crescent Societies.

Hart, R. 2009. The Use of Military Assets in The Humanitarian Response to Natural Disasters. Report on Wilton Park Conference 994. 
International Regime Approach in the Development of Indonesia's 2004 Post-Aceh Earthquake and Tsunami Disaster Regulations

OCHA, 2009. Reference Guide Normative Developments on the coordination of humanitarian assistance in the General Assembly, the Economic and Social Council, and the Security Council since the adoption of General Assembly resolution 46/182. New York: OCHA Policy Development and Studies Branch. 